\title{
Nutritional Recovery Outcome among Moderately Malnourished Under-five Children in Communities Implementing Positive Deviance - Hearth or Community Health Workers' Nutrition Promotion Approaches in Karusi and Kirundo Provinces, Burundi
}

\author{
Chantal Inamahoro ${ }^{1}$, Juliet Kiguli $^{2}$, Fredrick Edward Makumbi ${ }^{3}$, Gakenia \\ Wamuyu-Maina ${ }^{4}$ and Henry Wamani ${ }^{5}$
}

(C) Uganda Martyrs University

\begin{abstract}
The Positive Deviance - Hearth (PD-H) approach is important in controlling malnutrition; however, there is limited data on its effect in improving nutrition status. Objective: To assess the effect of PD-H and community health worker nutrition promotion (CHWNP) in improving nutrition status and recovery among the moderately malnourished under-five (MMU5) children in Burundi. Methodology: PD-H and CHWNP approaches were used in Karusi and Kirundo provinces, respectively. MMU5 children were enrolled at baseline for the intervention (PD-H, (358) and usual care (CHWNP, (310). Haemoglobin level and anthropometric indicators (MUAC, wasting, underweight and stunting) were taken at baseline for 12,60 and 120 days. Changes in nutritional recovery were compared within groups exposed to each approach using ANOVA for continuous outcomes and chi-square for categorical outcomes. Further analysis compared changes between the two groups exposed to the two approaches using random effects logistic models for binary outcomes and mixed effect models for continuous outcomes. Results: The MMU5 children discharged cured after 60 days and at 120 days follow-up. When compared with the baseline, this was statistically significant in both CHWNP and PDH groups on anthropometric indicators (wasting, underweight, stunting, MUAC and weight) but not anaemia. After controlling for socio-demographic factors, MMU5 enrolled in CHWNP were more likely to be discharged cured than those in PD-H with respect to moderate wasting $(\mathrm{AOR}=2.74,95 \% \mathrm{CI}=1.19-6.29)$, underweight $(\mathrm{AOR}=1.56,95 \% \mathrm{CI}=1.01-2.43)$ as well as MUAC $(\mathrm{AOR}=1.21,95 \% \mathrm{CI}=0.49-3.00)$. Conclusion: Both CHWNP and PD-H significantly improved nutrition status and recovery. However, the proportion of those who recovered was significantly larger in CHWNP compared to PD-H.
\end{abstract}

Keywords $\cdot$ Recovery rate $\cdot$ Community-based nutrition program $\cdot$ Nutrition status $\cdot$ Positive deviance Under-five

Résultat de récupération nutritionnelle chez les enfants de moins de cinq ans dans les communautés effectuant la déviance positive - foyer ou les approches de promotion de la nutrition par les agents de santé communautaire dans les provinces deKarusi et Kirundo, Burundi

${ }^{1}$ Makerere University, School of Public Health, *Corresponding author: cinamahoro@pathfinder.org

${ }^{2}$ Department of Community Health and Behavioral Sciences, Makerere University, School of Public Health

${ }^{3}$ Department of Epidemiology and Biostatistics, Makerere University School of Public Health

${ }^{4}$ Regional Centre for Quality Health Care, Makerere University School of Public Health

${ }^{5}$ Department of Community Health and Behavioral Sciences, Makerere University School of Public Health 
Résumé. L'approche de la déviance positive - Foyer (DP-F) est importante dans le contrôle de la malnutrition ; cependant ily a peu de données sur son effet sur l'amélioration de la nutrition. Objectif: Evaluer l'effect de la DP-F ainsi que la Promotion Nutritionelle par les Professionels de Sante Communautaire (PNPSC) pour l'amelioration de l'etat nutritionel et de la recuperation chez les enfants de moins de cinq ans souffrant de malnutrition modérée (EMM-5) au Burundi. Méthodologie: Les approaches de la DP-F et PNPSC ont ete deployees dans les provinces de Karusi et Kirundo, respectivement. Les EMM-5 y ont été inscrits pour une étude de base (358 pour DP-F) et soins reguliers (310 pour PNPSC). Le niveau de l'hémoglobine et les indicateurs anthropométriques ont été pris lors du début de l'étude, et après 12, 60 et 20 jours. Les changements dans la récupération nutritionnelle ont été comparés parmi les groups éxposés à chacune de ces approches à l'aide d'ANOV A pour les résultats continus et le Chi-square pour les résultats catégoriques. Une autre analyse a comparé des changements entre les deux groupes exposés aux deux approches à l'aide de modèles logistiques à effets aléatoires pour les résultats binaires et les modèles à effets mixtes pour les résultats continus. Resultats: Les EMM-5 ont complétement récupéré après 60 jours et à 120 jours de suivi. Et la comparaison avec l'étude de base démontre une difference statistiquement significative entre les deux groupes de PNPSC et DP-D concernant les indicateurs anthropometriques (l'émaciation, l'insuffisance pondérale, du retard, le MUAC et poids) mais pas de l'anémie. Après le contrôle des facteurs socio-démographiques, les EMM-5 inscrits dans le PNPSC étaient plus susceptibles d'avoir complétement récuperé que ceux inscrits dans le DP-D par rapport à l'émaciation modérée (AOR = 2.74, $95 \% C I=1.19-6.29)$, l'insuffisance pondérale $(A O R=1.56,95 \% C I=1.01-2.43)$, ainsi que le $M U A C$ $(A O R=1.21,95 \% C I=0.49-3.00)$. Conclusion: Les deux approches de PNPSC et DP-F ont considérablement amélioré l'état de nutrition et de récupération. Cependant, la proportion de ceux qui ont récupéré était significativement plus grande le PNPSC par rapport à la DP-F.

Mots-clés: taux de récupération • programme de nutrition à base communautaire • l'état nutritionnel • déviance positive • Sous-cinq ans

\section{Introduction}

Malnutrition remains a health challenge in Burundi. The rate of chronic malnutrition among children under five years has worsened, increasing by $10 \%$ from $48.1 \%$ in 1987 (Burundi Ministry of Home Affairs, 1988) to 58\% in 2010 (Burundi Ministère du plan et al., 2012). The rate of acute malnutrition increased by $0.4 \%$ from $5.6 \%$ in 1987 to $6 \%$ in 2010 (ibid) in the same period. This high prevalence of malnutrition has contributed directly or indirectly to high infant, child and maternal mortality in the country (WHO, 2005). A combined number of supply-side and demand-side factors have worsened the Nutritional status of under-fives in Burundi. First, acute malnutrition is managed using the community management of acute malnutrition (CMAM) approach; only cases of acute malnutrition are treated at health facilities. The CMAM approach consists of three components. Cases of moderate acute malnutrition (MAM) are managed through community outreach or at the health centre with supplementary feeding services (SFS) using Corn Soya Blend (CSB) as the therapeutic food. Cases of severe acute malnutrition (SAM) without medical complications are managed as outpatients using ready-to-use infant therapeutic food (RUTF) while cases of SAM with medical complications are referred to hospital for inpatient management using fortified therapeutic foods like F75 and F100 milk. Therapeutic foods are only served at health facilities.

The challenges to this approach include the fact that some of the therapeutic food intended to be given freely is either often out of stock or sold by caregivers (National Programme of Food and Nutrition, 2011). Healthcare providers focus on food distribution without explaining the importance of therapeutic food to caregivers to prevent them from selling it. In addition, there is low geographic access to SFS in the country; the World Food Program (WFP) currently supports only 40 (4.2\%) health centres out of a total of 937 (Directorate of National Health Information Systems, 
2013) However, the long distance to the facilitated therapeutic feeding centres poses access challenges. To address this challenge, the government and its partners initiated community-based nutrition care (CBNC) programs involving community health workers (CHWs). Specifically, the Community Health Workers Nutrition Promotion (CHWNP) approach was established. CHWNP is a community-based strategy using the existing CHWs to sensitise the community on health and nutrition and carry out screening and referral of malnourished children to health centres. Currently, various donors support the Ministry of Health to implement CBNC, particularly the Positive Deviance - Hearth (PD-H) approach which provides community-based rehabilitation for children with MAM using locally-available and affordable food (Pascale et al. 2010) The PD-H approach is based on the identification, dissemination and use of good practices already adopted by some community members living in the same conditions and at the same level of poverty as other families but whose children are well-nourished to solve nutritional problems existing in the community. Thus, it aims to scale up solutions already existing within a community (Sternin et al., 1998; Wishik and van Der Vynckt, 1976). However, at the time of this study, there was a gap in local knowledge on the effect of CHWNP and PD-H approaches on the nutritional status of moderately malnourished children, specifically on the duration to discharge and final cure rates. The present study assessed the effect of these two CBNC approaches on the nutrition status and recovery speed and rate among moderately malnourished under- five children in two provinces of Burundi.

\section{Methodology}

An interventional study was carried out in Karusi and Kirundo Provinces in the Eastern and Northern regions of Burundi, respectively. Both provinces are among those with the highest prevalence of malnutrition (Burundi Ministère du plan et Burundi Ministère de la Santé Publique et de la Lutte Contre le SIDA, 2012). The intervention spanned from March to September 2014. The study period included preparatory activities; nutritional surveys at baseline of 12 days, 60 days and 120 days post-baseline; as well as mid-term and end-term project evaluations. The PD-H intervention comprised intensive training of caregivers for 12 consecutive days followed by training of once a month for up to 4 months (120 days). During this training, malnourished children received the extra nutrition necessary for their rehabilitation, depending on their degree of malnutrition. Their caregivers received health education messages on key Positive Deviance behaviours related to new feeding methods, dietary intake, personal and environmental hygiene, as well as health care practices. These were demonstrated and rehearsed in groups during health sessions and, later practiced individually at home. After 12 days, CHWs or expert positively deviant mothers continued to give health education during home visits for up to 120 days. Evaluation of nutrition status was done after 12 days, 60 days and 120 days post-baseline.

A two-stage randomised cluster survey was conducted with a total sample of 840 under-five children aged 6 - 59 months with MAM (i.e., 14 children per village were selected from 30 villages per province, giving 420 children per province. This was based on the 2010 Demographic and Health Survey that showed a prevalence of 
stunting of $58 \%$ (IFAD, 2010). A margin error of 5\%, 95\% confidence level and a design effect (D) of 1.5) were used. In the first stage, 30 villages per province were randomly sampled with replacement. In the second stage, children in the village were screened for recruitment into the study starting from a random point at the centre of the village and following a randomly selected direction. The first 14 under-5 children found to have moderate malnutrition [(defined as having Weight for Height z- scores (WHZ), Weight for Age z-scores (WAZ) or Height for Age z- scores (HAZ) between -2 and $\geq-3$, or MUAC $\geq 11.5$ but less than $12.5 \mathrm{~cm}$ without pitting oedema)] were recruited if their caregivers consented to participate. The study team moved to the next selected village after recruiting 14 children. Among the 840 children initially enrolled in the study, 668 (79.5\%) had complete information on anthropometric and haemoglobin analysis. The remaining 172 (20.5\%) were excluded from the analysis due to worsening medical condition, lack of records on age, migration, and because of caregivers who refused to attend the sessions because the food given for rehabilitation was similar to what they had at home.

\section{Data collection procedure}

Data collection covered nutritional assessment and recovery monitoring. Assessment of the nutritional status mainly focused on taking anthropometric measurements while recovery monitoring included both anthropometry and monitoring micronutrient levels. At the onset of recruitment, there was a mass screening for malnutrition among under-5s. The recruitment was based on MUAC using a $26 \mathrm{~cm}$ MUAC measuring tape from Ningbo Finer Medical Instruments Co. Ltd. It was also based on a firstcome first served basis. MUAC of children aged 6-59 months was taken by study team members. Those found to have MUAC $\geq 11.5$ and $<12.5 \mathrm{~cm}$ were included in the study because they were considered as having moderate acute malnutrition. Weight, height and oedema were subsequently checked for the 668 children who met the recruitment criteria. The haemoglobin level was checked at baseline and at 120 days by fingertip capillary blood samples analysed with HemoCue HB201 ${ }^{+}$. Anaemia was defined as having haemoglobin below $11 \mathrm{~g} / \mathrm{dl}$ in accordance with WHO guidelines (WHO, 2001). Evaluation for weight gain was done at 12 days and subsequently with all other parameters at 60 and 120 days to assess the percentage of children recovered. The primary outcome was recovery from moderate acute malnutrition. Recovery was defined as having WHZ, WAZ or HAZ of $\geq-2$ z-score; MUAC $\geq 12.5 \mathrm{~cm}$, or weight gain of $>200 \mathrm{~g}$. Secondary outcomes included having a haemoglobin level of $>11 \mathrm{~g} / \mathrm{dl}$. Children who attained any one of the above indicators were discharged as cured. The numbers included at different stages of the study are shown in Figure 1. 


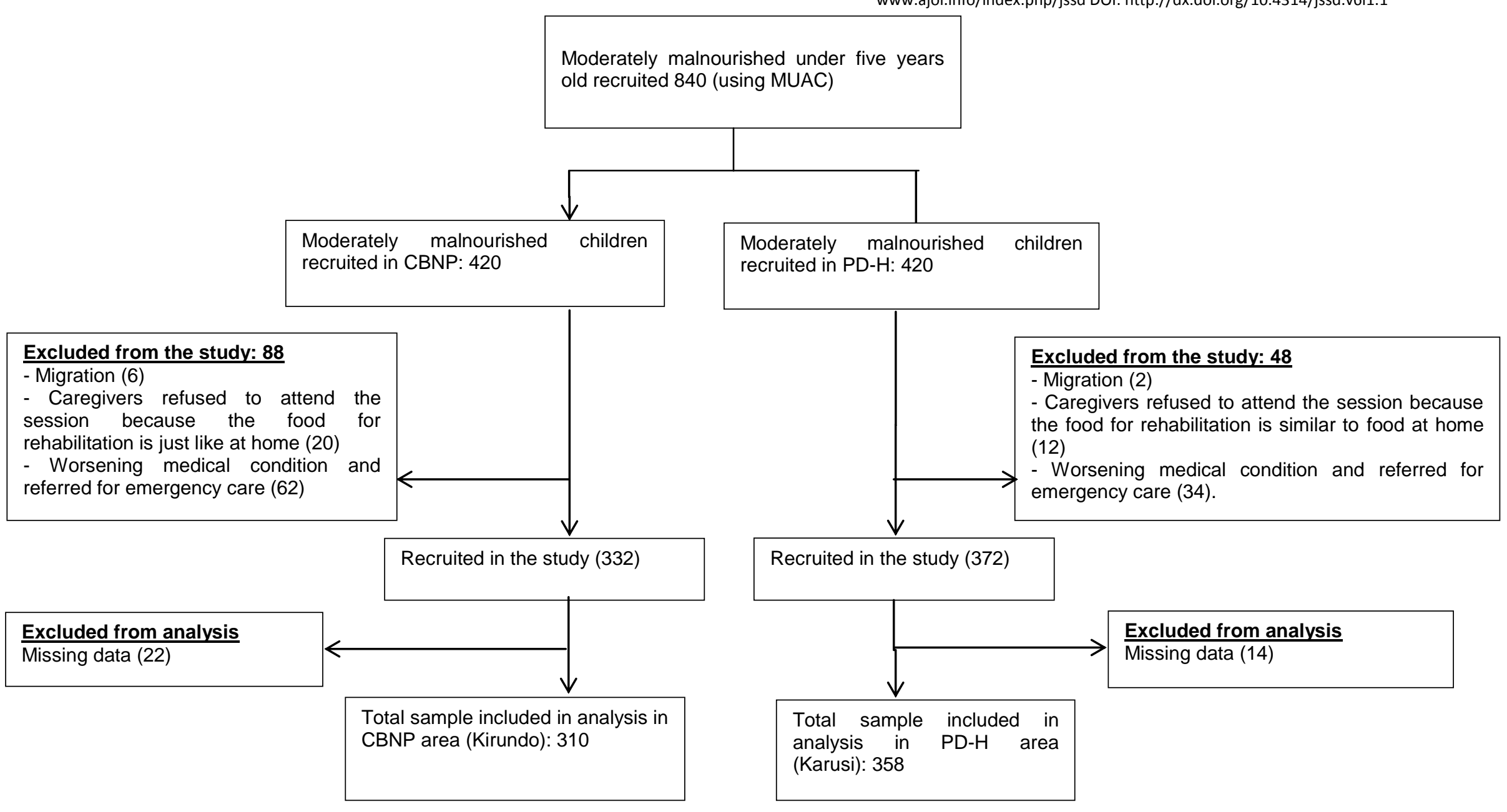

Figure 1: Schematic diagram of moderately malnourished children recruited and excluded as well as reasons for exclusion from the study 


\section{Statistical analysis}

At baseline, children's socio-demographic characteristics, anthropometric and haemoglobin measurements were compared between the two intervention groups. Proportions (for categorical data) and means (with SD, for continuous data) were compared between the intervention groups using Chi-square and t-tests, respectively; the statistical significance was determined at 5\%. After 60 and 120 days, respectively, comparative analysis was done for the same groups of interest within each approach. Weights, heights/lengths were compared with International WHO reference standards and converted to WAZ, HAZ, and WHZ using Epi-Info. Data analysis was done using SPSS version 17. Continuous variables were compared using ANOVA and categorical variables by using the Chi-squared test. The continuous variables within each approach were compared using McNemar's test with $\mathrm{p}<0.05$ considered to indicate statistical significance. Logistic regression analysis was used to assess the effect of PD-H and CHWNP activities on recovery. In bivariate analysis, sociodemographic characteristics of the child and mother were run against the primary outcome i.e., recovery. Any variable found to have $\mathrm{p}<0.15$ was considered a potential confounder and included in the multivariable model. Odds ratios were computed to assess the presence and degree of association between the proportion of MMU5 discharged cured and independent variables, e.g., socio-demographic variables like sex of the child, mother's age and education level, etc.

\section{Results}

The baseline socio-demographic characteristics of children and mothers in both approaches were as shown in Table 1. The lowest and highest age recorded for mother/ female caregivers was 18 and 56 years in both groups. In keeping with international standards, children who had a weight gain of $200 \mathrm{~g}$ and above were considered to have recovered. Over $60 \%$ of the children within each approach gained $>200 \mathrm{~g}$ by day 12 and the proportion increased to more than $90 \%$ by day 120 (Table 2). Furthermore, within each approach, there were statistically significant increases in proportions of children who had a weight gain $>200 \mathrm{~g}$ (recovered) from day 12 to 120 .

\section{Comparison of nutritional status changes in PD-H or CHWNP groups}

The proportion of MMU5 discharged cured based on MUAC, wasting, underweight and stunting in each approach was statistically higher at 60 days compared to the baseline (Table 3). In fact, recovery based on MUAC increased to more than $75 \%$ within each approach at 120 days. All these indicators were above the performance standards set by the National Protocol of Community Management of Acute Malnutrition (recovery from moderate acute malnutrition > 75\%) (UNICEF and PRONIANUT, 2005). However, within each study approach, the recovery from anaemia was not statistically significant in both groups (in CHWNP: 63.8 to $63.4 \%$; $\mathrm{p}=0.920$; in PD-H: 48.6 to $46.6 \%$; $\mathrm{p}=0.549$ ). 
Table 1: Socio demographic characteristics of children and their mothers/ female caregivers according to the implementation approaches

\begin{tabular}{|c|c|c|c|c|c|c|c|}
\hline \multirow[t]{3}{*}{ Variables } & \multicolumn{2}{|c|}{ Overall } & \multicolumn{2}{|c|}{ PD-H (Karusi) } & \multicolumn{2}{|c|}{ CHWNP (Kirundo) } & \multirow{3}{*}{ P-value } \\
\hline & $\mathbf{N}$ & $\%$ & $\mathbf{N}$ & $\%$ & $\mathbf{N}$ & $\%$ & \\
\hline & 668 & 100 & 358 & 53.6 & 310 & 46.4 & \\
\hline & \multicolumn{6}{|c|}{ Children's Characteristics } & \\
\hline \multicolumn{8}{|l|}{ Sex } \\
\hline Female & 357 & 53.4 & 201 & 56.1 & 156 & 50.3 & \\
\hline Male & 311 & 46.6 & 157 & 43.9 & 154 & 49.7 & 0.132 \\
\hline \multicolumn{8}{|l|}{ Age (months) } \\
\hline 6- 11 & 105 & 15.8 & 52 & 14.6 & 53 & 17.1 & \multirow{4}{*}{0.292} \\
\hline $12-23$ & 235 & 35.3 & 119 & 33.5 & 116 & 37.4 & \\
\hline 24-35 & 167 & 25.1 & 90 & 25.4 & 77 & 24.8 & \\
\hline \multirow[t]{2}{*}{$36-59$} & 158 & 23.8 & 94 & 26.5 & 64 & 20.6 & \\
\hline & \multicolumn{7}{|c|}{ Mother's/Female Caregivers' Characteristics } \\
\hline \multicolumn{8}{|l|}{ Age group } \\
\hline under 25 years & 154 & 23.1 & 78 & 11.7 & 76 & 11.4 & \multirow{4}{*}{0.123} \\
\hline 25 - 34 years & 298 & 44.7 & 166 & 24.9 & 132 & 19.8 & \\
\hline 35 - 44years & 150 & 22.5 & 72 & 10.8 & 78 & 11.7 & \\
\hline 45 years + & 64 & 9.6 & 41 & 6.2 & 23 & 3.5 & \\
\hline \multicolumn{8}{|l|}{ Parity } \\
\hline 1 child & 74 & 11.1 & 38 & 5.4 & 36 & 5.4 & \multirow{4}{*}{0.392} \\
\hline 2 - 3 children & 218 & 32.6 & 108 & 16.2 & 110 & 16.5 & \\
\hline 4 - 5 children & 224 & 33.5 & 124 & 18.6 & 100 & 15 & \\
\hline $6+$ children & 152 & 22.8 & 88 & 13.2 & 64 & 9.6 & \\
\hline
\end{tabular}


Table 2: Recovery rates (weight gain $>\mathbf{2 0 0} \mathrm{g}$ ) over time by implementation approach

\begin{tabular}{|c|c|c|c|c|c|c|}
\hline & \multicolumn{3}{|c|}{ PD-H (Karusi) } & \multicolumn{3}{|c|}{ CHWNP (Kirundo) } \\
\hline & $\begin{array}{ll}\text { Day } \\
(n=358)\end{array}$ & $\begin{array}{l}\text { Day } \\
(n=321)\end{array}$ & $\begin{array}{l}\text { Day } 120 \\
(n=298)\end{array}$ & $\begin{array}{ll}\begin{array}{l}\text { Day } \\
(n=310)\end{array} & 12\end{array}$ & $\begin{array}{l}\text { Day } 60 \\
(n=290)\end{array}$ & $\begin{array}{l}\text { Day } 120 \\
(n=258)\end{array}$ \\
\hline $\begin{array}{c}\text { Weight } \\
\text { gain }\end{array}$ & $\%(95 \% \mathrm{Cl})$ & $\%(95 \% \mathrm{Cl})$ & $\%(95 \% \mathrm{Cl})$ & $\%(95 \% \mathrm{Cl})$ & $\begin{array}{r}\%(95 \% \\
\mathrm{Cl})\end{array}$ & $\begin{array}{r}\%(95 \% \\
\mathrm{Cl})\end{array}$ \\
\hline$>200 \mathrm{~g}$ & $\begin{array}{c}63.7 \% \\
(58.9- \\
68.9)^{\star *}\end{array}$ & $\begin{array}{r}86 \%(81.6- \\
90.3)^{* *}\end{array}$ & $\begin{array}{r}91.9 \% \\
(88.5- \\
95.2)^{\star *}\end{array}$ & $\begin{array}{c}60.6 \% \\
(55.1- \\
66.1)^{\star \star}\end{array}$ & $\begin{array}{r}87.9 \% \\
(82.6- \\
91.3)^{\star *}\end{array}$ & $\begin{array}{r}92.3 \% \\
(88.5- \\
95.2)^{\star \star}\end{array}$ \\
\hline$>400 \mathrm{~g}$ & $\begin{array}{r}45.8 \% \\
(40.9- \\
51.2)^{* *}\end{array}$ & $\begin{array}{c}77.6 \% \\
(72.5- \\
82.4)^{\star *}\end{array}$ & $\begin{array}{r}87.9 \% \\
(84.191 .6)^{\star *}\end{array}$ & $\begin{array}{r}43.9 \% \\
(38.3- \\
49.4)^{\star *}\end{array}$ & $\begin{array}{c}79.3 \% \\
(76.1- \\
83.3)^{\star *}\end{array}$ & $\begin{array}{r}89.5 \% \\
(85.79- \\
3.3)^{* *}\end{array}$ \\
\hline $\begin{array}{r}\text { Mean } \\
(\mathrm{kg})\end{array}$ & $\begin{array}{l}0.38(0.30- \\
0.45)^{\star}\end{array}$ & $\begin{array}{l}0.75(0.69- \\
0.82)^{\star \star}\end{array}$ & $\begin{array}{l}1.04{ }^{(0.95-} \\
1.12)^{*}\end{array}$ & $\begin{array}{l}0.53(0.41- \\
0.62)^{\star \star}\end{array}$ & $\begin{array}{l}0.79(0.71- \\
0.86)^{\star}\end{array}$ & $\begin{array}{l}1.26(1.07- \\
1.35)^{\star \star}\end{array}$ \\
\hline
\end{tabular}

Table 3: Recovery rates over time by measure of nutritional outcome and implementation approach

\begin{tabular}{|c|c|c|c|c|c|c|}
\hline \multirow[b]{2}{*}{$\begin{array}{l}\text { Recovered by } \\
\text { Outcome measure }\end{array}$} & \multirow[b]{2}{*}{$\mathbf{N}$} & \multicolumn{2}{|c|}{$\begin{array}{l}\text { CHWNP- } \\
\text { Intervention } \\
\text { (Kirundo) }\end{array}$} & \multirow[b]{2}{*}{$\mathbf{N}$} & \multicolumn{2}{|c|}{$\begin{array}{l}\text { PD-H Intervention } \\
\text { (Karusi) }\end{array}$} \\
\hline & & 60 days & 120 days & & 60 days & $\begin{array}{l}120 \\
\text { days }\end{array}$ \\
\hline & & $\begin{array}{l}\%(95 \% \\
\mathrm{Cl})\end{array}$ & $\begin{array}{ll}\% & (95 \% \\
\mathrm{Cl}) & \end{array}$ & & $\begin{array}{l}\%(95 \% \\
\mathrm{Cl})\end{array}$ & $\begin{array}{l}\%(95 \% \\
\mathrm{Cl})\end{array}$ \\
\hline MUAC & $\begin{array}{l}28 \\
5\end{array}$ & $\begin{array}{l}61.4 \%(5 \\
6-67)^{\star *}\end{array}$ & $\begin{array}{l}81.9 \%(7 \\
6-85)^{\star \star}\end{array}$ & $\begin{array}{l}32 \\
6\end{array}$ & $\begin{array}{l}57.6 \%(5 \\
2-63)^{\star \star}\end{array}$ & $\begin{array}{l}75.1 \%( \\
69-78)^{\star \star}\end{array}$ \\
\hline Wasting & 71 & $\begin{array}{l}60 \% \\
(54-66)^{\star *}\end{array}$ & $\begin{array}{l}69 \%(58- \\
80)^{*}\end{array}$ & $\begin{array}{l}10 \\
3\end{array}$ & $\begin{array}{l}41.5 \%(3 \\
6-47)^{\star \star}\end{array}$ & $\begin{array}{l}46.6 \%( \\
37-56)^{*}\end{array}$ \\
\hline Underweight & $\begin{array}{l}21 \\
8\end{array}$ & $\begin{array}{l}12 \%(8- \\
17)^{\star \star}\end{array}$ & $\begin{array}{l}24.3 \%(1 \\
9-30)^{\star \star}\end{array}$ & $\begin{array}{l}24 \\
8\end{array}$ & $\begin{array}{l}12 \%(8- \\
16)^{\star \star}\end{array}$ & $\begin{array}{l}14.5 \% \\
(10-19)\end{array}$ \\
\hline Stunting & $\begin{array}{l}22 \\
8\end{array}$ & $\begin{array}{l}9 \% \\
13)^{\star \star}\end{array}$ & $\begin{array}{l}11.8 \% \\
(8-16) \\
\end{array}$ & $\begin{array}{l}26 \\
4 \\
\end{array}$ & $\begin{array}{c}9 \% \\
(6-12)^{\star *} \\
\end{array}$ & $\begin{array}{l}9.8 \%(6- \\
13)\end{array}$ \\
\hline Anaemia & $\begin{array}{l}19 \\
8\end{array}$ & - & $\begin{array}{l}0.4 \%(0.2 \\
-0.98)\end{array}$ & $\begin{array}{l}17 \\
4\end{array}$ & & $\begin{array}{l}2 \%(0.4- \\
4)\end{array}$ \\
\hline
\end{tabular}

* for $\mathrm{P}<0.05 ; * *$ for $\mathrm{p}<0.005$

\section{Factors influencing recovery}

Among the MMU5 enrolled for the PD-H approach, MUAC recovery was associated with mothers' education (Primary education and above compared to no formal education: OR 1.26, 95\% CI 1.02-2.51, $\mathrm{p}=0.045)$. The influence of other expected factors (mothers' age, child's sex) was not statistically significant (Table 4). Among the MMU5 enrolled for the CHWNP approach, mothers' age between 34 and 45 was significantly associated with recovery from wasting (OR 5.78, 95\% CI $1.26-13.54, \mathrm{p}=0.024)$. Other factors were not significantly associated with recovery. 
Table 4: Child and maternal factors significantly associated with recovery based on MUAC, wasting and underweight.

\begin{tabular}{|c|c|c|c|c|}
\hline \multirow[b]{2}{*}{ Characteristics } & \multicolumn{2}{|c|}{ PD-H (Karusi) } & \multicolumn{2}{|c|}{ CHWNP (Kirundo) } \\
\hline & OR & $95 \% \mathrm{Cl}$ & OR & $95 \% \mathrm{Cl}$ \\
\hline \multicolumn{5}{|c|}{ Recovery from acute malnutrition (MUAC) } \\
\hline $\begin{array}{l}\text { Child's sex: Female } \\
\text { Mother's age }\end{array}$ & 0.79 & $(0.48-1.3)$ & $0.30^{*}$ & $0.20-0.7$ \\
\hline Under 25 years & 1.0 (ref) & & 1.0 (ref) & \\
\hline $25-34$ years & 1.32 & $0.68-2.58$ & 1.25 & $0.58-2.67$ \\
\hline $35-44$ years & 0.97 & $0.43-2.16$ & 1.08 & $0.46-2.55$ \\
\hline 45 years + & $2.06^{*}$ & $0.88-4.8$ & 0.71 & $1.18-2.79$ \\
\hline \multicolumn{5}{|l|}{ Mother's education } \\
\hline No level & 1.0 (ref) & & 1.0 (ref) & \\
\hline Primary and above & $1.26^{*}$ & $0.92-2.51$ & 1.15 & $0.59-2.24$ \\
\hline \multicolumn{5}{|c|}{ Recovery from wasting (WHZ) } \\
\hline Child's sex: Female & $0.44^{*}$ & $0.20-0.97$ & 0.6 & $0.2-1.94$ \\
\hline \multicolumn{5}{|l|}{ Mother's age } \\
\hline Under 25 years & 1.0 (ref) & & 1.0 (ref) & \\
\hline $25-34$ years & 0.81 & $0.28-2.32$ & 1.13 & $0.24-5.29$ \\
\hline $35-44$ years & 0.83 & $\begin{array}{l}0.23-3.03 \\
0.090\end{array}$ & $5.78^{*}$ & $1.26-26.53$ \\
\hline 45 years + & 0.37 & 1.52 & 1.08 & 0 \\
\hline \multicolumn{5}{|l|}{ Mother's education } \\
\hline No education & 1.0 (ref) & & 1.0 (ref) & \\
\hline Primary and above & 1.34 & $0.56-3.19$ & 0.67 & $0.21-2.14$ \\
\hline \multicolumn{5}{|c|}{ Recovery from underweight (WAZ) } \\
\hline $\begin{array}{l}\text { Child's sex: Female } \\
\text { mother's age }\end{array}$ & $0.80^{*}$ & $0.39-1.64$ & $0.47^{\star}$ & $0.25-0.89$ \\
\hline Under 25 years & 1.0 (ref) & & 1.0 (ref) & \\
\hline $25-34$ years & 1.91 & $0.79-4.65$ & 1.64 & $0.76-3.52$ \\
\hline 35 - 44years & 1.28 & $0.46-3.6$ & $2.25^{*}$ & $0.91-5.59$ \\
\hline 45 years + & 1.5 & $0.42-5.32$ & 1.50 & $0.46-4.87$ \\
\hline \multicolumn{5}{|l|}{ Mother's education } \\
\hline No level & 1.0 (ref) & & 1.0 (ref) & \\
\hline Primary and + & 0.98 & $0.46-2.12$ & 1.40 & $0.68-2.90$ \\
\hline
\end{tabular}

${ }^{*}$ for $p<0.05 ;{ }^{* *}$ for $p<0.005$ 


\section{Recovery from moderate malnutrition in PD-H and CHWNP groups}

The odds of recovery based on MUAC among the under-five malnourished children in CHWNP were about 50\% higher than in PD-H $[\mathrm{OR}=1.48 ; 95 \% \mathrm{CI}(1.01-2.17)]$ (Table 5). In addition, recovery from wasting among the under-five malnourished children in CHWNP was 2.55 times higher than that in PD-H [OR=2.55; 95\% CI (1.35- 4.81)]. Similarly, for the CHWNP approach, the odds of recovery from underweight among malnourished children was about $89 \%$ higher than that in PD-H approach [OR=1.89; $95 \% \mathrm{CI}(1.18$ - 3.02)]. In controlling for socio-demographic factors, malnourished children recruited in CHWNP had 2.74 times higher chance of recovery from wasting compared to those recruited in $\mathrm{PD}-\mathrm{H}(\mathrm{AOR}=2.74,95 \% \mathrm{CI}=1.19-6.29)$.

Table 5: Recovery at 120 days by implementation approach

\begin{tabular}{lllll}
\hline Discharge cured / Recovery & CHWNP & PD-H & ODD RATIO (95\% Cl) & Adjusted OR (95\% Cl) \\
\hline Based on MUAC & & & & \\
Yes & $81.90 \%$ & $75.10 \%$ & & \\
No & $18.10 \%$ & $24.90 \%$ & $1.48(1.01-2.17)$ & $1.21(0.49-3.00)$ \\
\hline From wasting & & & & \\
Yes & $69 \%$ & $46.60 \%$ & & \\
No & $31 \%$ & $53.40 \%$ & $2.55(1.35-4.81)$ & $2.74(1.19-6.29)$ \\
\hline From underweight & & & & \\
Yes & $24.30 \%$ & $14.50 \%$ & & $1.56(1.01-2.43)$ \\
No & $75.70 \%$ & $85.50 \%$ & $1.89(1.18-3.02)$ & \\
\hline From stunting & & & & $0.84(0.45-1.57)$ \\
Yes & $11.80 \%$ & $9.80 \%$ & & $1.23(0.69-2.17)$ \\
No & $88.20 \%$ & $91.20 \%$ & & \\
\hline
\end{tabular}


Mixed effect models also showed more significant recovery in the CHWNP group at 60 and 120 days post-baseline, with wasting improving by $15 \%$ (coefficient $0.151, \mathrm{p}<$ 0.001) (Table 6).

Table 6: Analysis of malnourished children enrolled in CHWNP based on recovery from malnutrition using GEE

\begin{tabular}{llll}
\hline $\begin{array}{l}\text { Recovery } \\
\text { measure }\end{array}$ & Beta & SE & P \\
\hline MUAC & 0.046 & 0.0071 & $<0.001$ \\
\hline Underweight & 0.033 & 0.0076 & $<0.001$ \\
\hline Wasting & 0.151 & 0.0206 & $<0.001$ \\
\hline Stunting & 0.001 & 0.0068 & 0.892 \\
\hline
\end{tabular}

\section{Discussion}

In the present study, the overall mean weight gain after 120 days was statistically significant in both the PD-H and CHWNP groups. This was similar to Bolles et al's (2002) study that reported a significant increase in weight gain among children less than 5 years enrolled in PD-H in Haiti. The present study also showed more improvement in weight gain in the CHWNP group than the PD-H group. This finding is in agreement with a study by Ghoneim et al. (2004) in Egypt which showed significant weight gain among children following similar interventions. Bisits (2011) also showed positive results in nutrition outcomes in children and positive behaviour change in carers.

The present study also suggested that recovery was associated with the sex of the child in both implementation approaches. However, the relationship was not statistically significant, just like in previous studies (Zottarelli et al 2007; UNICEF Burundi, 2013) and in disagreement with Manu (2006) who reported that food consumption was lower among girls compared to boys or Bundervoet et al. (2009) who showed that there existed gender bias (favouring boys) in food distribution in low-income households, especially, during food-shortage seasons. The results also suggested that recovery was strongly associated with mothers aged 35 years and above, although the relationship was not statistically significant. Okafor (2002) found that mothers' age is a determining factor for children's nutritional status. This finding would not be surprising given that mothers in the age group of 15-25 are more or less still inexperienced in home and child care. The chance of nutritional recovery also seems to increase with mothers' level of instruction increases, thus agreeing with Ujiro and Idehen (2007) and UNICEF Burundi, (2013). Both assert that mothers who received even minimal education are generally more aware than illiterate mothers, on how to utilise available family resources to improve the nutritional status of family members. 
Recovery based on wasting after 120 days (4 months) was statistically significant in both CHWNP and PD-H groups, thus agreeing with what Savadogo et al. (2011) found in Burkina Faso. Generally, the nutrition indicators used in the present study were found to be above the performance standards set in the Burundian National Protocol of Community Management of Acute Malnutrition (Ministère de la Santé Publique et de la lutte contre le SIDA, 2014). There was no statistically significant change in haemoglobin levels in any of the intervention groups. This could be due to inadequate specific focus on anaemia prevention during the intervention period. Although the children were dewormed and received vitamin A supplementation before the present study, it was still necessary to provide nutrition education focusing on anaemia prevention as well as iron supplementation.

\section{Conclusion and recommendations}

This study shows that both community-based nutrition care and Positive Deviance approaches can improve nutrition status and increase nutritional recovery among children under-five years of age. It also demonstrates that recovery was faster and in higher proportions using the community health worker nutrition promotion approach compared to the PD-H approach. However, the broader generalisation of the findings is affected by an overall small sample size, which affects the power of the study. They were also affected by varying sample sizes at the analysis stage due to the differential withdrawal of malnourished children in the two intervention groups. Intention-to-treat analysis would have been a better approach to analysis but it was hampered by lack of data due to loss of follow up. We, nevertheless, recommend a greater focus on the use of CHWs in prevention and management of childhood malnutrition, as well as enhancing community-level efforts to prevent anaemia through nutrition education on dietary sources rich in iron coupled with provision of iron supplements to pregnant women. We also recommend intensified childhood growth monitoring right from birth to establish a baseline for nutritional guidance and counselling at the community level. Finally, we recommend a non-inferiority trial of the PD-H and CHWNP approaches to definitively establish the more effective option and compare their sustainability at the community level.

\section{References}

Bisits Bullen, P.A., 2011. The Positive Deviance/Hearth approach to reducing child malnutrition: systematic review. Tropical Medicine \& International Health 16(11) 1354-66

Bolles, K., Speraw, C., Berggren, G., \& Lafontant, J.G., 2002. Ti Foyer (hearth) community_ based nutrition activities informed by positive deviance approach in Leogane, Haiti: Programmatic description. Food Nutr Bull 23 (4) 11-17

Bundervoet, T., Verwimp, P. \& Akresh, R., 2009. Civil war, crop failure and child stunting in Rwanda. Economic Development and cultural change 59(4) 777-810

Burundi Directorate of National Health Information System., 2013. Statistical year book for health centres and hospitals data 2012 
Burundi Ministère de la Santé Publique et de la Lutte Contre le SIDA., 2014: Protocole Nationale de la Prise en Charge Intégrée de la Malnutrition Aiguë (PCIMA): Version Révisée. Bujumbura: Minisanté

Burundi Ministère de l'intérieur et de la formation patritiotique, 1988. Demographic and health survey of Burundi 1987.

Burundi Ministère du plan, Burundi Ministère de la santé publique et de la lutte contre le SIDA, 2012. Burundi demographic and health survey of Burundi 2010.

Ghoneim, E.H., Hassan, M.H., \& Amine, E.K., 2004. An intervention programme for improving the nutritional status of children aged 2-5years in Alexandria. East Mediterr Health J 10(6) 828-43.

IFAD, 2010. Rapid nutrition survey for estimating impact. [Online] Available From: http://www.ifad.org/gender/tools/hfs/anthropometry/ant_3.htm [Accessed 3 January 2011]

Zottarelli, L.K., Sunil, T.S., \& Rajaram, S., 2007. Influence of parental and socioeconomic factors on stunting in children under 5 years in Egypt. East Mediterr Health J 13(6) 1330-42

Manu, Khetarpaul., N., 2006. Gender differences in food consumption pattern and nutrient intake of Indian pre-school children (3- 4 years) in Haryana State. Nutr Health 18: 141- 9

Okafor, J. O., 2002. Principles of healthful living ( $2^{\text {nd }}$ edition). Onitsha: Erudite publisher.

Pascale, R.T., Sternin, J., \& Sternin, M., 2010. The power of positive deviance: How unlikely innovators solve the world's toughest problems. Boston, Massachusetts, Harvard Business Press

Savadogo, L., Zoetaba, I., Donnen, P., Hennart, P., Sondo, B.K., \& Dramax, M., 2011. Management of moderate and severe acute malnutrition in an urban nutrition rehabilitation center in Burkina Faso. Rev Epidemiol Santé Publique: 55: 256-74

Sternin, M., Sternin, J., \& Marsh, D., 1998. Designing a community based nutrition program using the hearth model and the positive deviance approach - a field guide for save the children. [Online] Available From: http://www.positivedeviance.org/pdf/fieldguide.pdf [Accessed 3 January 2011]

Ujiro, R.I., \& Idehen, F.B., 2007. Infant health management. Lagos: University of Lagos Press.

UNICEF \& PRONIANUT Burundi, 2005: National Protocol of Community Management of Acute Malnutrition

UNICEF, 2013. Child malnutrition - a situation analysis. UNICEF Burundi

UNICEF, 2010. National Programme of food \& Nutrition, annual report. UNICEF Burundi

WHO, 2005. Messages for world health Day. [Online] Available From: http://www.who.int/world-healthday/previous/2005/tookit/messages/en/index1html [Accessed 3 January 2011].

WHO, UNICEF, \&United Nations University. Iron deficiency anaemia, assessment, prevention and control: A guide for programme managers. Geneva. 
Wishik, S.M., \& Van Der Vynckt, S., 1976. The use of nutritional 'positive deviants' to identify approaches for modification of dietary practices. American Journal of Public Health 66(1) 38-42.

\section{Authors' Biography}

Chantal Inamahoro (MSc) is the Country Representative of Pathfinder in Burundi and South Kivu-DRC. She is an international public health professional with over 13 years of experience. She previously worked as senior technical advisor in the Ministry of Health.

Juliet Kiguli (PhD) is an anthropologist teaching in the Department of Community Health and Behavioural Sciences. She has over 23 years of teaching experience at Makerere University. She specialises in conducting qualitative research on food security, community engagement, health behaviour and development work.

Fredrick Makumbi (PhD) is an Associate Professor and former department chair of epidemiology and biostatistics at the school of public health, Makerere University. He teaches Biostatistics, Epidemiology, Demography and research methods. A member of institutional review boards at Uganda Virus research Institute and the National AIDS Research Committee. His research includes clinical and community-based trials, male circumcision and reproductive health.

Gakenia Wamuyu Maina (PhD) is a public health nutritionist with over twenty years experience in nutrition programming, capacity building, research, outreach and consultancy. Her interests are community and clinical nutrition, HIV/AIDS, maternal and child health, IEC and policy.

Henry Wamani (PhD) is a Lecturer and Researcher, School of Public Health, Makerere University, for the last eight years. He coordinates a Master's degree programme on Public Health Nutrition. Previously, he worked with the Uganda Ministry of Health, World Health Organisation and USAID. 